\title{
Between the Nile and the Red Sea
}

\section{Medjay Desert Polities in the Third to First Millennium всЕ}

\author{
Julien Cooper \\ Research Centre for History and Culture, Beijing Normal University \\ at Zhuhai, Zhuhai, China \\ BNU-HKBU United International College \\ juliencooper@uic.edu.cn
}

\begin{abstract}
The Medjay were a group of desert nomads inhabiting the region between the Nile and the Red Sea contemporaneous to the Bronze Age of Ancient Egypt (c. 3100-1050 BCE). Well-known from textual sources from Pharaonic Egypt and Kushite Nubia, it has proven difficult to produce basic societal descriptions of the Medjay and their political status, especially in their desert heartland. Most studies dedicated to the Medjay evaluate their presence as a nomadic diaspora and emigres on the Nile or focus on their interaction with the Ancient Egyptian state. These approaches place little emphasis on their indigenous geography and nomadic heritage in the Red Sea Hills. This study takes a very different tact and attempts to reconstruct some basic information on their political geography in their indigenous homeland. Although the sources, both textual and archaeological, are currently scarce regarding a Second Millennium вCE desert occupation, they do demonstrate complex arrangements between Medjay political actors and nearby states. Particularly notable was the ability of individual tribes to enact varying policies of entente, détente, and aggression towards their Nile neighbours as well as exercise de facto sovereignty over a wealthy desert consistently threatened by Egyptian and Kushite imperialism.
\end{abstract}

\section{Keywords}

Eastern Desert - Medjay - Egypt - Nubia - Northeast Africa - ancient history - archaeology

In terms of social organisation and subsistence lifeways the Medjay people mentioned in Egyptian documents were originally and quintessentially desert 
nomads. Their desert existence almost deterministically largely defines them as nomads who kept goats, sheep, and cattle, where the transhumant life had them roaming across a vast desert in search of water and pasture. Sources concerning the Medjay over the span of Pharaonic culture demonstrate two distinct, yet interrelated, populations signalled by the word 'Medjay' in relevant texts. In the first use this term, it designated a population who was indigenous to the Eastern Desert of Nubia and likely also Upper Egypt. This use is common in the texts of the Old and Middle Kingdoms. The second use of this term, as emphasized by Gardiner and a numbers of scholars since, ${ }^{1}$ was its application to a diaspora community that seemingly originated from the desert but lived within and around the Egyptian and Sudanese Nile, slowly being culturally divorced from their desert homeland. This 'diasporic Medjay' is first observed in the texts from the Middle Kingdom (c. 2000 BCE) and by the New Kingdom accounts for the majority of textual references to the word 'Medjay'. On the other hand, there is no specific reason to suspect that there was not always an ongoing input and outflow of pastoralist nomads on the Nile since millennia immemorial, possible based on factors of seasonal nomadism and pasturing. Thus the 'Medjay diaspora' was likely in perpetual existence, albeit with a pronounced episode in the Middle Kingdom and later. With a mind to establishing the political map of Northeast Africa and the foreign neighbours of the Egyptian state, this contribution aims to describe and analyse the political organization of the Medjay in the 'first use' of the term - namely establish what Medjay polities existed in the desert and develop a picture of their socio-political structure or their geographical layout. ${ }^{2}$ In world-historical terms, this is roughly concordant to what some call the 'Nubian Bronze Age', a term that is not without problems in this region.

The peopling of these deserts and our view of local political organization in Northeast African deserts is a difficult subject to broach. Quintessentially, the scholarly geo-political model of ancient Northeast Africa has only identified 'complex' political organisations on the Egyptian and Sudanese Niles, the states of Egypt and Kush and sometimes the intervening space in Lower Nubia - leaving the deserts as rather 'empty' regions even if there is acknowledgement of local nomadic groups. ${ }^{3}$ This approach is concomitant with perceptions of pastoral nomadism and desert-living as not being conducive

1 Gardiner (1947:*82) and Liszka (2010:317-319).

2 Although this use of the word 'Medjay' falls out of use in Egyptian documentation of the New Kingdom and later, this research takes the regional groupings of Ibhet and Ikyet to be the cultural successors of the Medjay world.

3 There are of course exceptions to the pure nomadism of the desert in the agricultural regions of the Ethiopian Highlands or the Kassala region in the Sudanese-Ethiopian borderlands, see Manzo 2017a. 
to the formation of confederating or unifying forces; chiefly urbanism and agricultural surplus. But counter examples for state and empire building in marginal areas are widespread and well-known, such as Late Antique North Arabia or Mongol-Turkic Central Asia. These processes, however, are seldom applied in the historiography of Northeast Africa. Much of this political map of Northeast Africa is driven by the specific scholar's fields (anthropologists, archaeologists, historians) and their methodological, definitional, and evidential criteria as to what constitutes a polity, state, or complex political organisation. ${ }^{4}$ For archaeologists, political organisation is suggested by an ensemble of specific objects and features pointing to unified political organisation: seals, administrative paraphernalia, symbols of elite power, urbanism, or monumental architecture. For the historian, the search is usually geared to some explicit or implicit mention of a common leader or political entity in texts and literature - for example the mention of Kush in Egyptian sources as a signal for the existence of an Upper Nubian polity based at Kerma. ${ }^{5}$ For an anthropologist or political theorist, methodological approaches are driven by complex definitional criteria as to what constitutes an ancient polity; 'universal membership', 'political pull factors', or 'integrated economies' being a few of the many complex criterion. In all of the above approaches, our task is biased towards our evidential criteria and theoretical basis of what constitutes complex political arrangements. Reversing our epistemological approach somewhat, one might pragmatically counter that complex political arrangements within and amongst neighbouring peoples are comparatively inevitable no matter what the subsistence based economy. ${ }^{6}$ If we are unfamiliar with these arrangements in indigenous histories it is only due to the illusory mirage of the 'absence of evidence'. In pre-textual and nomadic societies, the predisposition of complex political arrangements can be no different. Urbanization, monumental architecture, or literacy, while comparatively common features of ancient states are not at all universal pre-conditions for complex polities. With this approach in mind, this analysis, without driving for a definitional goal of 'state', 'polity', or even 'nomadic organisation' for the ancient Medjay of the Eastern Desert, aims to illustrate what we can say about local political organisation in the deserts east of the Egyptian and Sudanese Niles.

4 For the problems of defining ancient states in non-urban settings, see Sneath (2007:8-9, 48ff). See also the related problem of focusing on the evolutionary model of 'chiefdom' societies in McIntosh (1995:1-30).

5 Zibelius (1972:166-167). It seems likely, following El-Sayed (2011:274), that the placename Kush specifically refers to a polity in Upper Nubia rather than just a geographical region or territory.

6 Layton 1986:18-33. See also the comments regarding inequality in hunter-gatherer societies in McIntosh 1995:4-5. 


\section{Social Organisation — Some Realities}

Egyptian texts are exceedingly vague and stereotyped concerning foreign peoples on both their immediate and distant periphery. This is partly attributable to the nature and genre of the majority of sources which are not inherently descriptive or analytical in outlook but rather served a specific ideological purpose of inserting 'foreigners' into an established Egyptian worldview and cosmic order. ${ }^{7}$ What is emphasized when these texts mentioned foreigners is not anything inherent about the foreigners themselves but encounters in Egyptian expeditionary endeavours abroad. In attempting to describe a Medjay political structure from Egyptian sources, we are indeed using the sources for something that they were not intended and must read 'between-the-lines' as it were. On the other hand, there is a genre of 'documentary texts', letters, economic documents, and so forth, that do give a much more vivid and objective picture of local affairs not tainted by the dogmatic brushstroke of Egyptian political ideology. These documents, specifically fortress missives and expedition receipts, while comparatively rare, do describe local and complex administrative affairs.

Archaeological evidence for Medjay 'drop-sites' or nomadic camps is relatively under-developed and requires much further work. Some surveys in the Eastern Desert have found ceramics belonging to the phase c. 2500-1000 BCE, but disturbingly no unequivocal cemeteries are known from this period. ${ }^{8}$ The place of the 'Pan-Grave people', an eponymous burial tradition and ceramic culture, in this discussion of Medjay society is important. ${ }^{9}$ The Pan-Grave people likely represent an intrusive material culture on the Nile Valley that spread throughout the Nile from Middle Egypt to Lower Nubia and perhaps in other regions too, typified by their by distinctive shallow burials, burial assemblages, and distinctive pottery. If the Pan-Grave represent the forming of a 'nomad diaspora' on the Nile, then the material culture of this group is submissible for reconstructing societal information about the desert Medjay. However, excavated Pan-Grave sites are largely ascribable to the second use of the term 'Medjay' as a diaspora minority community living on the banks of the Nile. Recent research delineating ceramic typology of the Pan-Grave people with stratified contexts and carbon dates has proposed a convincing model where the traditions Pan-Grave of the Egypto-Nubian Nile and the Gebel Mokram of Kassala region represent one large cultural horizon relating to Eastern Desert

\footnotetext{
7 Consult Diego Espinel (2006).

8 Sadr 2004: 197. See also the site gazette in Castiglioni et al. 1995:112-118, 177, 181.

9 See now de Souza 2019:16-17, 140-150.

10 Manzo 2017a:65-68.
} 
dwellers. ${ }^{10}$ While it would epistemologically simplistic to use Pan-Grave cemeteries on the Nile as societal information for desert Medjay, a few cultural facets of this population demonstrate a decidedly pastoralist culture with links to the desert such as the existence of Red Sea shells and desert minerals. ${ }^{11}$ In particular, the painting of cattle skulls in votive deposits represents some ritual importance or familial bond with the herd and particularly cattle. ${ }^{12}$ The maintenance of this 'cultural nomadism' seems evident even when the Pan-Grave people live within the agricultural urbane population of the Nile, especially in regards to their burial deposits of cattle, sheep, goat, and gazelle.

Whatever the stereotypes produced in Egyptian texts and artistic representations, we must turn to a pragmatic reality of what Medjay society likely entailed. With a homeland in a vast desert east of the Nile, life would have largely been on the move and of a seasonal nature. Specialized pastoral nomadism, a subsistence pattern based on the movement of the herd across the landscape, was well developed by the Third Millennium вСЕ in this part of Northeast Africa. Seeking pastures and water was the main goal of this transhumance - and we can expect that the desert in this distant past was much more favourable to herding movements in the veritably 'greener' climate east of the Nile. ${ }^{13}$ There are some indications that these ancient nomads even practiced cattle pastoralism, a ruminant activity that would now be impossible in all but the most southerly climes of the Sudanese Eastern Desert. ${ }^{14}$ An inherent part of this nomadic activity was the social unit that travelled together; 'tribes' or 'extended family groups'. These traveling units would have been kept small as to not place too much pressure on the landscape. An ancient glimpse on such a unit is contained in the Semna Dispatches, the missives from Egyptian border fortresses in Lower Nubia. In one report describing the encounter of desert migrants with a frontier patrol near a fortress, there is a rendezvous with a small band of Medjay, three men, and four children..$^{15}$ Papyrus Boulaq 18, documenting incoming Medjay families to Theban palace, documents two Medjay families; one with two 'chiefs', two 'followers', one 'interpreter (?)', and

\footnotetext{
11 de Souza 2019:7-8, 149 .

12 Cooper \& Barnard 2017. The Ptolemaic historian Agatharchides stresses the importance of cattle to Eastern Desert peoples, the Trogodytes. The connection was so strong that they ascribe the descriptor and appellation of 'parents' to cattle, see Burstein (1989:111).

13 For descriptions of Beja transhumance and herding strategies, see Hjort \& Dahl (1991:134-150).

14 Bobrowski, et al 2013. For epigraphic evidence of this, see also (Cooper in press).

15 Smither 1945:7-8.
} 
one 'child' ${ }^{16}$ Such sources give some indication of the basic travelling family unit - the major unit of social importance in pastoralist nomadic spheres.

The contemporary Beja social unit equivalent to the extended family, the diwab, is the mainstay of identity and the institution in which land-rights are invested. Superordinate to the diwab identity groups that linked together the diwab in a larger tribal conglomeration was the adat (also Arabic gabila 'tribe'). ${ }^{17}$ Such social units or their close equivalents are now and probably were always the norm in the desert landscape. Importantly for the analysis of Beja political units, it is the ancient version of the adat that we must look for, superordinate tribal identities that take the form of a polity - whatever the anthropological jargon or term one might apply to such formations.

How a diwab or adat would manifest itself archaeologically is an important consideration for future survey work. Western scholars travelling through Beja lands in the $19^{\text {th }}$ century described a number of nomad 'capitals', one of the most notable being Filik, the main camp of the powerful confederacy of the Hadendowa Beja near the Gash Delta. ${ }^{18}$ Burckhardt described Filik as being an extended camp of 100-200 tents and straw huts (tukul) centred near a group of wells. The function of this encampment seems to have been a gathering place for Hadendowa families, being a useful for pasture as well as a strategic trading and market locale on the route between the Nile and the Red Sea coast. Elsewhere camps were much smaller and were chiefly aligned to the subsistence activities of the family group.

\section{The First Desert Rulers}

The earliest desert rulers traceable in historic records were the Medjay of Pharaonic Egyptian sources who, on the evidence of their onomastic record, seem to have spoken an ancestral form of Beja. ${ }^{19}$ A rock inscription in the Aswan region mentions an unnamed $h k_{3}$ 'ruler' of Medjay alongside the $h k 3$ riverine polities of the Nubia such as Wawat and Irtjet as early as 2280 ВСE, although the vague and stereotyped language of the inscription does not present us with any specific information beyond the fact that Egyptians and Medjay were in contact. ${ }^{20}$ Not long after this, there is evidence that the

16 Other arrivals of Medjay chiefs are mentioned, but the numbers of people are not clearly recorded in the ledger, see Scharff (1922:13**).

17 For Beja social and lineage terminology, see (Morton 1989:50-51) and (Harir 1996:83ff).

18 Burckhardt 1819:386-387.

19 Zibelius-Chen (2006:729-733).

20 Sethe 1933:111. 
Egyptians incorporated some Medjay soldiers into their army. ${ }^{21}$ This measure was probably beneficial for both sides, providing a skilled set of nomadic desert specialists in the Egyptian military and diversifying the employment of the nomads away from pure pastoral subsistence. An Egyptian expedition of the early Middle Kingdom (c. 2000 BCE), the expedition of the great steward Henu, seeking aromatic products of the southern Red Sea and the land of 'Punt', mentions that the aromatics trade was controlled by a plurality of headmen, 'rulers of the desert'.22 These rulers must have been the leaders of various tribes encountered by Egyptian expeditions. The Egyptians were thus cognizant of the fact that they needed to deal with multiple such tribes and leaders to secure precious aromatics and safe passage through the desert. In this same expedition narrative, Henu mentions that some local desert nomads were employed by the Egyptian expedition to defeat other 'rebel' nomads who prevented them reaching the Red Sea coast: "The watchmen cleared a way before overthrowing the rebels of the king, the hunters and the children of the desert were set as the protection of my limbs". ${ }^{23}$ Different tribes could facilitate or alternatively harm Egyptian expeditions in the desert, leading to conflict. Vague ideological mentions of military exploits against the Medjay of early Middle Kingdom kings indicate that Egyptian state had some interest in controlling the deserts, but conversely also demonstrate that the Medjay themselves did not suffer free exploitation of their desert and its gold produce unchecked. ${ }^{24}$ Whatever the limits of their power, they could at the very least prevent exploitation of their lands. But on the whole this conflict paradigm should be balanced with the symbiosis of trade. Medjay peoples traded desert cattle with Egyptians and likely are the hidden hand in the success of its gold enterprise. $^{25}$

Our best records of specific Medjay personages comes from the late Middle Kingdom (c. 18 оо в Ве >). In what was a common practice throughout the period, Egyptian scribes transcribed the names of foreign rulers and domestic dissenters on magical figurines known as the Execration Texts. ${ }^{26} \mathrm{~A}$ series of these inscribed objects found at the sites of Helwan, Mirgissa, Thebes, and Saqqara form a connected corpus of texts giving us a snapshot of foreign dynastic lineages of the Levant and Nubia in the late Middle Kingdom.

\footnotetext{
21 Manassa 2016:151-163.

22 Couyat \& Montet 1912:82.

23 Hieroglyphs in Couyat \& Montet 1912:82.

24 Marochetti 2010:11-12.

25 Vernus 1986:141-143.

26 The primary sources are (Sethe 1926:34-5, 37, 39-40); (Koenig 1990: 105-6); (Posener 1940 :

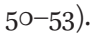




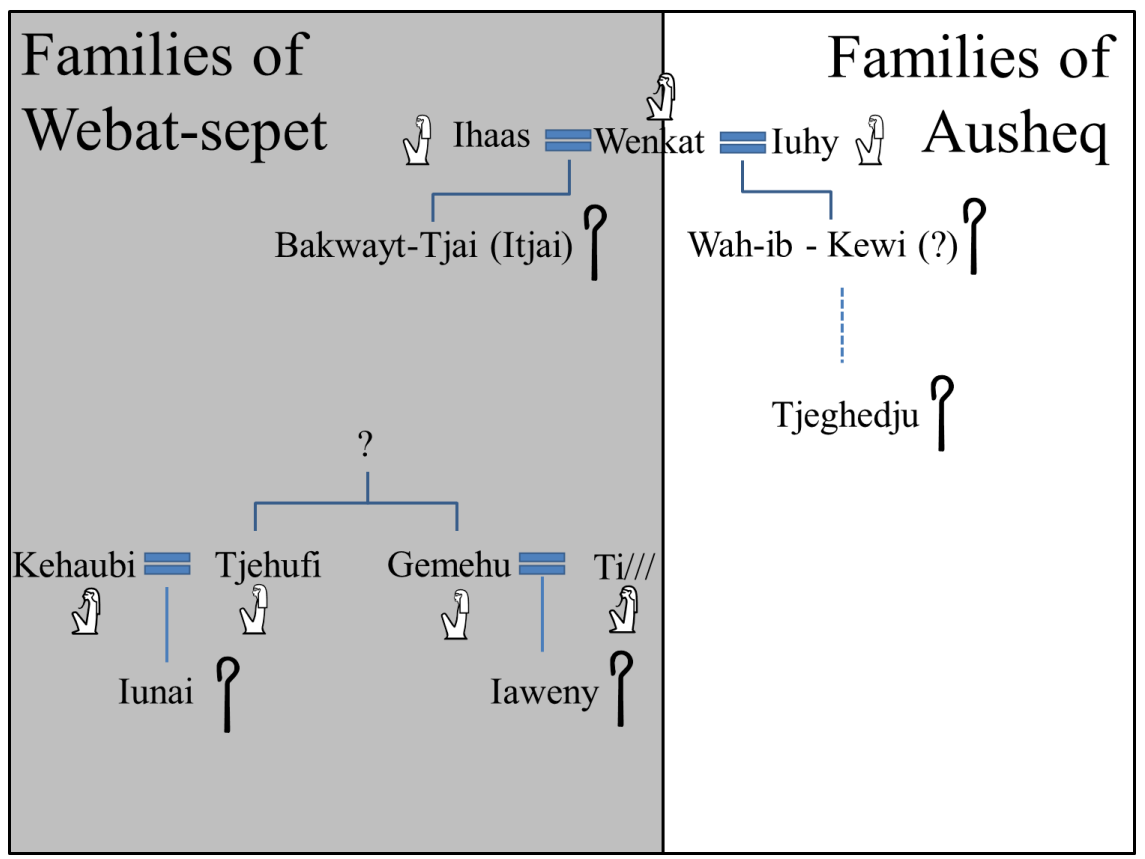

FIGURE 1 Medjay families of the late Middle Kingdom (1800-1700 BCE) as outlined in the

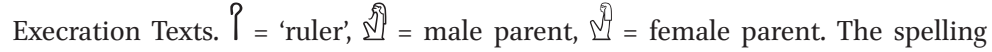
of names follows Egyptological convention, and is not an accurate phonetic transcription

Reconstructing the Medjay section of these texts, it is possible to trace the noble lineages in the desert heartland (Fig. 1), although it is worth pointing out that these texts were definitely not genealogical in design but had the purpose of magical recitation of a voodoo-like ceremony. Rather, for the Egyptian user of these magical voodoo-texts, knowing the parentage and correct pronunciation of the individual was considered advantageous for the purpose of pacifying the foreign enemy.

Just what kind of society did these nomads rule? Taking some hints from our sources and with a mind for ethnographic parallels it is possible to arrive at a few basic conclusions as to the political organisation of the desert in various periods. In the Egyptian Pharaonic sources, there was a plurality of polities - each with established ruling families. These polities, in the Middle Kingdom records, were named Ausheq and Webat-sepet. The lineages of the polities of Ausheq and Webat-sepet were each dynastically tied to an ancestor called Wenkat. Unless Wenkat refers to two identically named individuals, he evidently had two separate wives, each bearing different lineages of rulers. There are little indications on how rulership was passed down in this ancient period 
but Muslim scholars noted the medieval Beja, the linguistic descendants of the Medjay, practiced matrilineal succession. Al-Aswani, in the tenth century, mentions a particular type: ${ }^{27}$

Their genealogies are through the female line. Each clan has a chief from amongst them; but they have neither a great chief nor religion. They leave inheritance to the daughter's son and the sister's son, excluding the son. They say that the progeny of the daughter and the sister are above suspicion. This is so because such progeny, whether begotten legitimately or out of wedlock, remain the sister's or the daughter's offspring.

As a proposition, matrilineal succession would explain how the Webat-sepet polity had the appearance of even more royal lineages, because succession was passed on to the son of the sister. So the ruler in the Theban texts, Iaweny, born of Gemehu (mother) and Ti// (father) passed on his succession to his sister's or daughter's son, Iunai, the son of Tjehufi and Kehaubi. This would make Tjehufi the sister or daughter of Iaweny. Another possibility that must be mentioned is that Iaweny may have had no heirs, and therefore succession passed onto Iunai, which would not be evidence of matrilineal inheritance but rather extinguished lines. Also worthy of note is the fact that consistently in the Execration Texts the mother is listed first rather than the father. Another earlier set of Execration Texts seems to demonstrate a possible element of matrilineal importance - when quoting a foreign rulers' parentage rather than just saying 'born of' the text says 'born of his mother', possibly indicating an Egyptian understanding of local matrilineal succession across Nubia in the Second Millennium вCE. ${ }^{28}$

This subject of Beja matrilineality has been discussed by a number of authors who postulated external influences for both matrilineal (Kushite) and patrilineal (Arabic) succession systems on the medieval Beja. ${ }^{29}$ It might be easier, however, if this evidence is taken to be positive for matrilineality, to posit an original matrilineal descent amongst Northern Cushitic speakers and the Medjay. Indeed, the Kushite connection or influence in Beja matrilineality makes little sense if we take the Kushite dynasties in the Execration Texts into account which seem to show patrilineal succession. ${ }^{30}$ Adding to this

27 Translation in Kheir 1989:56.

28 This is only encountered in the Helwan Execration Texts, see Posener 1987:18-19. See also Redford (2004:27).

29 Morton 1989:7-8.

$30 \quad$ For the Kushite family tree, see Ryholt (1997:254) and Cooper (2018:151-161). 
possibility, matrilineal succession or inheritance is prevalent in the region. The nearby Kunama practice matrilineal succession amongst ritual offices and it is also mentioned by Arab authors in medieval Nubia. ${ }^{31}$

It would appear that both Wenkat's sons (Itjai and Wah-ib) were given Egyptian language sobriquets in addition to their indigenous names, something that would only be likely if there was regular contact, be it trade or diplomatic, with Egypt. By the Thirteenth Dynasty (c. 1800-1650 BCE), PanGrave people, the possible archaeological corollary of Eastern Desert dwellers on the Nile, were already arriving in the Nile Valley. ${ }^{32}$ Ausheq had a single dynasty, whose rulers apparently visited the Theban palace. ${ }^{33}$ The mere entry of nomadic rulers to the Theban palace suggests some form of entente and mutual understanding between Egyptians and Medjay rulers. The Webat-sepet polity had at least two and possibly three ruling families. This conforms to typical organisation and kinship of tribal or clan groups, each group ruling over a separate and established territory but being tied to each other through shared language, kinship and intermarriage as well as more regular conduct like trade.

Judging from the number of tribal dynasties present in Webat-sepet, it might have been a larger territory than Ausheq. Indeed, the desert territorial span of these polities must have been quite massive, possibly delineating the entire expanse of the Eastern Desert from Upper Egypt and deep into Eastern Sudan (Fig. 2). Each of these dynasties would have had a large swathe of the desert in their possession - ruling over smaller family groups. Based on migration patterns and access of resources, it is likely that these polities were positioned longitudinally, each possessing a part of the Red Sea coast, the Red Sea Hills where the best watered valleys are located, and access to the Nile Valley. In an exceptional papyrus documenting the accounts of the Theban palace, several family groups of Medjay arrived including an exceptional envoy that included the 'chief of Ausheq' named Kewi. The arrival of Ausheq nomads at the palace perhaps suggests that this region was closer to Upper Egypt, ${ }^{34}$ including broad desert region east of Aswan and the Berenike coast. Conversely, the other tribal territory Webat-sepet is included in a list of tribute alongside that of Kush in the Annales of Amenemhat II, ${ }^{35}$ positioning this territory in the deserts further south, perhaps the reach of deserts east of the Third to Fifth Cataracts.

\footnotetext{
31 Dore (2007:453); Bechhaus-Gerst (2011:236-237).

32 Manzo 2017b:98-112.

33 Scharff 1922:51-68.

34 Ibid 51-68.

35 Altenmüller \& Moussa 1991:9.
} 


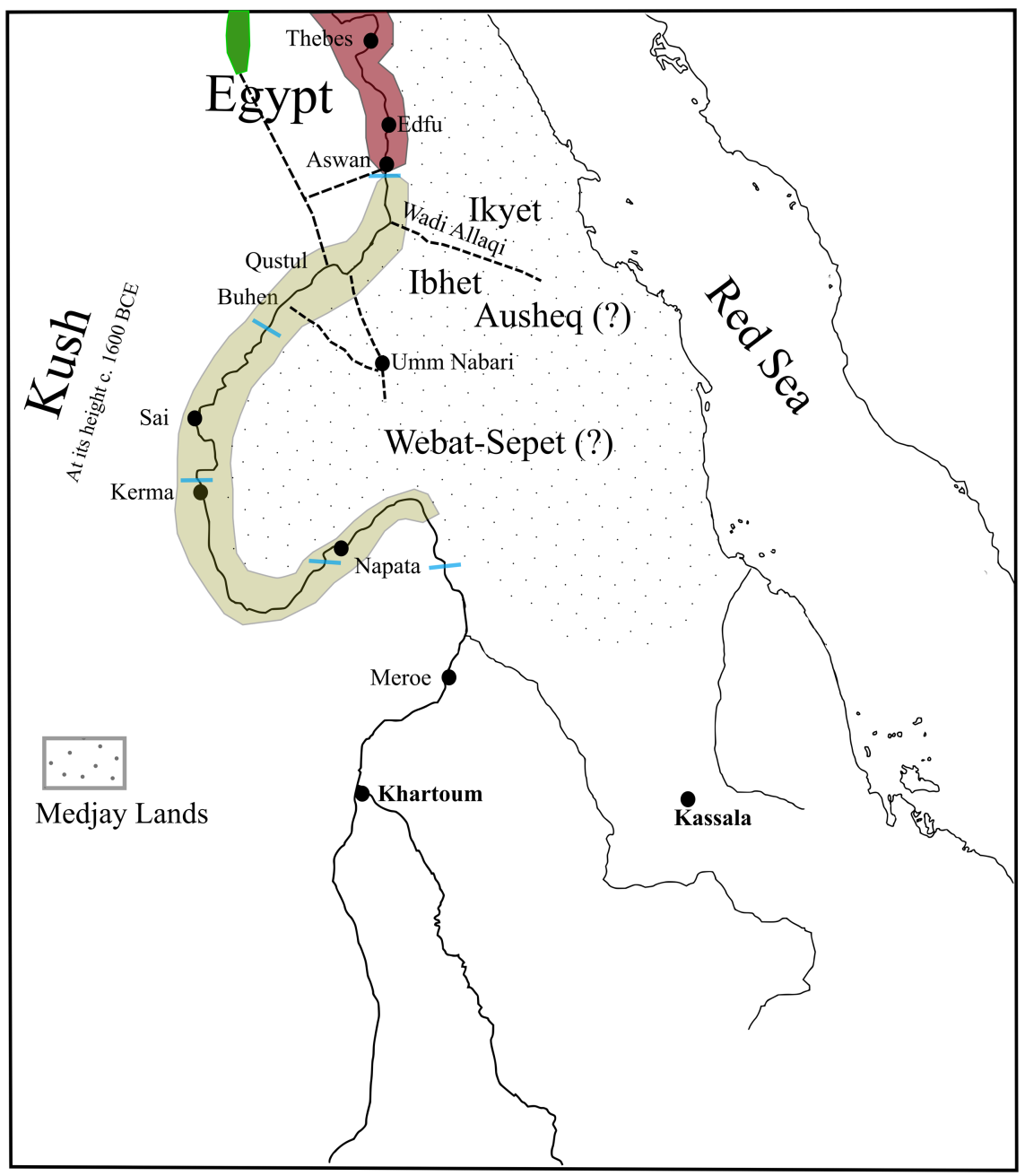

FIGURE 2 Map of Egypt and Sudan with the Medjay lands of the Eastern Desert

The Second Intermediate Period brought shockwaves not only to the Egyptian state but also changed the political configuration of wider Northeast Africa. Dominating Lower Egypt for over a century, by с. 1500 вСе, the Hyksos name would be erased from Lower Egypt. The Kushite state centered at Kerma, in its ascendency throughout this period, would so too succumb to the domination of Egypt, all but being destroyed as an independent polity under successive raids of early New Kingdom kings. So too, the Medjay confederations of Ausheq and Webat-sepet disappear from our record. The desert was not immune to these machinations. A number of changes must have gone through the desert heartland in this period. In an exceptional document narrating raids 
against Egypt, Medjay are described as joining the Kushite-led raids against Egypt. But not long after, other Medjay groups joined Egyptian forces in their reconquest of Hyksos controlled Lower Egypt. ${ }^{36}$ There was no necessity for Medjay groups to act in concert, and one can expect a complex relationship with the diaspora Medjay who had made a veritable home on the Nile during the height of this conflict. The Kushites also had their own designs on the Eastern Desert and its gold supply. After wresting control of Lower Nubia from the Egyptians, a Kushite ruler set up an inscription on the Korosko Road deep in the Medjay's deserts, demonstrating their new suzerainty over desert routes. ${ }^{37}$ Such ventures are probably what had cajoled certain tribes to their cause in the wars of the Second Intermediate Period.

The labeling of pastoral nomadic spaces, Ausheq, Webat-Sepet, and 'Hillcountries of Medjay' provided for some challenges in labelling and required flexibility for Egyptian scribes. The presence of a nomad diaspora in Egypt as well as the migration or assimilation of nomadic people of the 'Pan-Grave' culture may also have affected the make-up of New Kingdom desert polities.

\section{Desert Affairs in the New Kingdom}

The internal affairs of the desert are little known in the period of the Egyptian New Kingdom (c. 1550-110о вCE). The resurgent Egyptian state and its administration in colonial Nubia evidently exercised a degree of hegemony in this period but episodes of conflict severely curtailed unabated exploitation of desert resources. Local Egyptian rock inscriptions, largely attributable to goldmining parties and military officials, proliferate all parts of the Medjay deserts from Upper Egypt to the deserts east of Upper Nubia. ${ }^{38}$ Dedication texts and annales speak of truly massive amounts of gold being extracted from the desert, and Egyptian viceroys, the highest colonial officials in Nubia, doubled as 'overseers of gold' ${ }^{39}$ These viceroys of the early New Kingdom, Turoy (Amenhotep I-Thutmosis I), Seni (Thutmosis I-Hatshepsut), Amenemnekhu (Hatshepsut), evidently toured the desert to extract resources from the nomads, especially

36 Habachi 1972:48; Davies 2003:52-54.

37 Davies 2014:35-36.

38 See Davies 2014:30-44; Damiano-Appia 1999; Piotrovsky 1983.

39 Vercoutter 1959:120-153. Note one has to take a lower figure for gold production than Vercoutter's, as the gold deben weight is not 91 grams but rather 13.1 grams, which would give a figure of approximately 15 o kg between year 32 and year 42 of Thutmosis III, see Klemm \& Klemm (2013:23-24). 
incense and gold. ${ }^{40}$ After the reign of Amenhotep III, the lack of mentions of 'Medjay tours' and increasing references to military campaigns demonstrates the likelihood of renewed conflict with the desert polities. ${ }^{41}$ The Egyptian colonial machine had turned the desert into a huge extractive province, providing gold and aromatics as well as other exotic produce. Unfortunately, the archaeology of goldmines and goldmining is not sufficiently developed as to answer questions on the nature of this extractive and exploitative practice did the nomads take part in mining? Did the Egyptian state cajole nomads into mining? It is difficult to be sure of either scenario, but references to military officials in local rock inscriptions in the desert and the campaign reports of viceroys suggest that the gold supply was frequently interrupted by violence and conflict between Egyptians and nomads. ${ }^{42}$

But the evidence of Egyptian texts hardly promotes a nuanced or local understanding of historical dynamics in this period. For a more local view, one of the best pieces of evidence is a papyrus that deals with the affairs of the Coptite desert and gold mining teams. This papyrus (pCairo ESP) mentions that the indigenes of the desert, the men of Ikyet, were escorting a team of 'gold-washers', defending them from the predatory raids of rival Shasu nomads, Semitic speakers from the deserts further north near the Gulf of Suez. ${ }^{43}$ In what is perhaps an enigmatic reference to social status amongst the indigenous Eastern Desert dwellers, the Ikyet people are described as 'feather-wearing', a qualifier which Schulman thought might refer specifically to their chiefs rather than ordinary tribesemen. ${ }^{44}$ These 'feather-wearing' Ikyet-people were given rations to distribute by the Egyptian state. Whatever the case of their 'Egyptian mission', these local rulers had their own designs and were not wholly pacified nor were they always cooperative to Egyptian plans. The text also mentions that the nomads should not attack Egypt - evidently even though they worked for Egyptians the nomads were not always reliable allies or mercenaries. Such texts delineating alliances and multiple vying nomadic groups in the goldfields signify to us that the desert world had its own complex politics and historical

\footnotetext{
40 For Amenemnekhu, see Caminos 1998: pl.14; Davies 2008:55. For Turoy, see Habachi 1959:49. For Seni, see Caminos 1998:pl. 20-22.

41 See n. 46 for large New Kingdom military campaigns into the Eastern Desert. Most of these campaigns seem to be responses to Medjay raids.

42 For the 'Deputy of the troops Hornakht' in the middle of the Eastern Desert, see Davies 2014:33.

43 Wente 1990:38-39. For analysis of the geography in this document, see Cooper 2020: 198-200.

44 Schulman 1982: 299-306; Bryan 1991: 332-335.
} 
dynamics. This was not just a binary frontier between Egyptians and Medjay nomads, but a borderland witnessing local conflicts between Semitic- and Beja-speaking nomads under the aegis of Egyptian and Kushite supremacy.

Commemorative stele of Egyptian viceroy officials in Nubia under Amenhotep III and Akhenaton mention reprisal campaigns against the desert polities of Ibhet and Ikyet, both located in the region east of Lower Nubia and the Wadi Allaqi and Wadi Gabgaba basins. ${ }^{45}$ These campaigns importantly illustrate that the practice of nomads raiding the Nile Valley had already become a practice by about 1400 BCE, an early exemplar for the proliferate Blemmyean raids in Late Antiquity. ${ }^{46}$ The Egyptian reprisal raids also give some societal information for these early nomadic communities. In one raid against a nomadic encampment in the desert, Egyptians captured a total of 740 people, consisting of 150 men, 110 warriors, 250 women, and 175 children. A further 312 'hands' were taken from those killed, giving a total size of the nomad community as 1,052. A desert campaign under Ramesses II, directed by his viceroy Setau, refers to the 'chief of Ikyet' who was captured along with his wife, children, and 'crew', no doubt his retainers and servants. ${ }^{47}$ This chief's position was evidently cemented in his society to the degree that he could support his own retinue.

The Annales of Kushite kings of Napata and Meroe (c. 7OO-200 BCE) do mention encounters with Eastern Desert groups, but little information can be gleaned from these records. Evidently these encounters, mentioning cattle as well as women and children, were not so much battles but better explained as nomadic seasonal movements into the valley. Such movements, still common in the regions of the Fourth Cataract, no doubt led to infractions with the Kushite state. In the Annales of Harsiyotef (4O4-369 вСЕ) the Rehrehs, generally considered to be a tribe of Eastern Desert nomads, conducted a raid against Meroe in year 18 , led by a certain Kheru. ${ }^{48}$ Another chieftain called Iru of the Rehrehs tribe also led a raid into Meroe along with a man named Shiker in year 23. An earlier campaign by the Kushites against another enemy group called the Meded resulted in the death of their leader Saurireg//ti. ${ }^{49}$ In none of these texts are the persons specifically described as chiefs or rulers. But one of the named individuals, Kheru in the year 18 campaign, very likely represents

45 Discussion in Zibelius-Chen 1994.

46 There are three verifiable New Kingdom campaigns into this desert, that of Thutmosis IV (Helck 1955:1545-1548), Amenhotep II (ibid, 1659-166o) and Akhenaton (Helck 1995:63-65).

47 Helck 1975:85-112.

48 (FHN I, no. 78). For commentary, see Török (2009:368-70).

49 His name is damaged in the text. 
the modern Beja word had'a 'lord, sheikh', later transcribed in Coptic script as khara. ${ }^{50}$ This makes it likely that the name Kheru was a title or sobriquet for a tribal chief and might suggest even at this point in history there was an established 'elite class'. After this period, the use of the untranslatable Meroitic language in local inscriptions (c. $200 \mathrm{BCE}-400 \mathrm{CE}$ ) means that we are uncertain of the relationship between Nubia and the nomads.

\section{A Tribal Desert}

The Eastern Desert before the common era was a space with a multiplicity of tribal-based polities, some of whose nomad elites were interrelated and shared some vaguely defined political bonds. Despite shared subsistence patterns, language, and possibly familial bonds, it is evident that these desert polities did not always have friendly relations with each other. Even earlier in the Middle Kingdom, some Medjay who acted as patrolmen of the Egyptian fortresses secured the desert borders against their Medjay brethren coming to the Nile from the desert. ${ }^{51}$ Furthermore, it is likely, given the pastoralist nomadic nature of these groups and the pressures of finding ample pasture and water that individual Medjay groups came to disputes over tribal territory and land-use. Inter-ethnic livestock raiding is endemic in many pastoralist societies, especially in East Africa and the Horn, and is a culturally ubiquitous form of economic redistribution in East African pastoralist societies. The Nuer and Dinka, as well as the Turkana practiced this to varying degrees, as did the Beja. ${ }^{22}$ The classical geographer Agatharchides remarks of the Trogodytes, the classical period analogues of the Medjay: ${ }^{3}$

They do not fight with each other, as the Greeks do, over land or some other pretext but over the pasturage as it sprouts up at various times. In their feuds, they first pelt each other with stones until some are wounded. Then for the remainder of the battle they resort to a contest of bows and arrows. In a short time many die as they shoot accurately because of their practice in this pursuit and their aiming at a target bare of defensive weapons. The older women, however, put an end to the battle by rushing in between them

50 Zibelius-Chen (2006:729-733); Wedekind (2010:75-76). The Egyptian $r$, due to its place of articulation, can render the sound of a foreign $/ \mathrm{d} /$.

$5^{1} \quad$ Smither 1945:7-8.

$5^{2}$ For this practice in the Beja, see Harir (1996:90-9).

53 Burstein 1989:114. 
and meeting with respect. For it is their custom not to strike these women on any account so that immediately upon their appearance the men cease shooting.

There is no certain mention of cattle raiding among related Blemmyean tribes although some other circumstantial evidence suggests this was practiced against external enemies and therefore likely a feature in Blemmyean society. ${ }^{54}$ Nevertheless, the pastoral cycle and pressures of finding adequate pasture in an environment which had unreliable rainfall produced the ingredients for frequent low level internecine conflict. ${ }^{55}$ Whatever the case of internal conflict, the Medjay frequently joined their Nile neighbours in their wars and could band-together to raid Egypt. The number of 1,052 killed and captured nomads in the Amenhotep III raid on Ikyet represents a significant population in the context of Late Bronze Age nomadic societies.

\section{A Question of Scale}

Another approach to the historical dynamics of the region, rarely employed in the historiography of ancient Northeast Africa, is the notion of demographic scale. Vis-à-vis their Egyptian and Kushite counterparts, the total population of the Eastern Desert would have been small given its low carrying capacity and pastoralist subsistence. Demographic estimates for Ancient Egypt in the New Kingdom usually range around somewhere between two and three million inhabitants, giving scope for a growth of population to the known census figure of 4.75 million in Roman Egypt. ${ }^{56}$ For Kush and Sudan there is little in the way of reliable figures from which to extrapolate, but Trigger guessed a population of 17,500 for New Kingdom Lower Nubia (c. 1550-1100 BCE) based on cemetery data. ${ }^{57}$ The population of Egypt was sustained through dense agricultural settlement on the Nile and its massive carrying capacity, increasing over time as agricultural techniques became more efficient and urban centres integrated into a large network of international exchange. What would be the case in the desert? There are precious few figures from which one can

54 The Letter of Phonen mentions that Silko stole the Blemmyes' cattle (FHN III, no. 313). The Vita Shenoute also describes Blemmyes taking cattle (FHN III, no. 301).

55 For pastoralist conflicts arising from ecological causes, see McCabe (2010).

56 Kemp 2006:48-59.

57 Török 1997:44-49. 
extrapolate population estimates. The anthropologist Hobbs who conducted ethnographies of the northern Eastern Desert near Lower Egypt in the recent past guessed at a figure of one person per $9 \mathrm{okm}^{2}$ for the northern part of the Eastern Desert (Ma'aza territory). ${ }^{58}$ Taking the entirety of the Eastern Desert of Upper Egypt and Sudan into account, this would give a quite unlikely small figure of roughly 5,000 inhabitants. There are a multitude of reasons to think the ancient population figure must be much larger than this. Firstly, the ecological carrying capacity of the Eastern Desert in Sudan would have been much higher than Ma'aza territory, and this would have been amplified in antiquity when there are palaeoclimatic records for wetter conditions, especially in the Red Sea Hills and its higher altitudes which attracted orographic rainfall. ${ }^{99}$ Textual references to numbers of captured and killed in campaigns from the Eastern Desert are also indicative of a much higher figure than 5,000 . The figure of 1,052 killed and captive enemies in Amenhotep III's campaign and a later medieval campaign into the Eastern Desert under Ezana (c. $330 \mathrm{CE}$ ) where he captured and resettled 4,400 Beja indicate much higher populations. ${ }^{60}$ Both these datapoints refer to campaigns directed against finite regions of the Eastern Desert and not the entire desert. Furthermore, Amenhotep III's campaign and the figure of 1,052 is roughly comparable to the figures of captives sustained on Egyptian campaigns into the urban centres of the Levant. ${ }^{61}$ Viewed in this manner, conflicts on the desert periphery demonstrate the importance of this ignored 'peripheral' theatre of the Pharaonic state. There is no accurate strategy of estimation based on these figures but if individual regions of the desert contained in the order of thousands of people, it holds that the desert in its entirety cannot have had a population any less than 20,000 and likely much higher when taking into account the greater densities in the Red Sea Hills. While this is still a much smaller population than that of Ancient Egypt, it allowed for a concentration of population large enough to participate and sustain in exchange networks, joint raiding parties against Egypt, and conduct gold-mining ventures, especially when one considers this population was largely mobile. It also provided enough density to the desert as to prevent any free exploitation of unoccupied land.

\footnotetext{
58 Hobbs 1989:2.

59 Williams 2019:263-265.

6o See Hatke (2013:126) for the numbers in Ezana's campaign and n. 46 for Amenhotep III's text. The number in Amenhotep III's campaign is more remarkable if we take the statement that these people were captured 'in one day and one hour'.

61 Schulman 1982:305-306.
} 


\section{Conclusion}

This enduring theme of disunity in the ancient Eastern Desert until Late Antiquity does not mean that these nomads did not exercise local power and challenge the Egyptian state. ${ }^{62}$ The space was defined by a set group of tribal lineages each of which exercised their own local power. While social life was likely defined by small family units, some evidence suggests that these groups went through periods of greater and looser cooperation but never reaching a level that would define an inter-cultural political unity. Their social organisation, while fragmented, allowed local decision making, and there are some signs of cooperation in joining or harassing Egyptian expeditionary ventures into the desert. The Medjay peoples could evidently form ad hoc alliances with Egyptians and Kushites, and also paradoxically aid and attack Egyptian expeditions and raid the Nile in Egypt and Nubia. Local decision making gave maximum flexibility and adaptation to the changing status quo. In all periods, there are signs of a local elite of various regions such as Ausheq, Webat-sepet, and Ikyet. Each of these polities possessed an established ruler which likely passed on rulership in a matrilineal pattern. These rulers sometimes travelled to the Nile with their families and retinue and should be considered the local 'desert elite' and ruling class. Some were given Egyptian sobriquets and therefore likely developed an entente with Egypt but they were also responsible for organizing raids and rebellions. Beyond these basic descriptions, it is difficult to say more about the local Medjay political landscape. Without local archaeological data in the Second Millennium BCE, particularly the data from burials, it would be premature to suggest how these peoples exercised local power and how the Medjay polities 'fit' into the political map of Northeast Africa. Approximately speaking, the Medjay lineages were a milieu of culturally linked pastoralists spread across a wide arc of desert between the Nile and the Red Sea. Together, these lineages constituted a vital link in the exchange networks and political machinations of Northeast Africa.

\section{Bibliography}

Altenmüller, Hartwig and Moussa, Ahmed (1991). Die Inschrift Amenemhets II. aus dem Ptah-Tempel von Memphis. Ein Vorbericht. Studien zur Altägyptische Kultur 18 , pp. $1-48$.

62 For later periods of unity in the desert, see Cooper (2020). 
Bechhaus-Gerst, Marianne (2011). The (Hi)story of Nobiin - 1000 Years of Language Change. Frankfurt: Peter Lang.

Bobrowski, Przemysław, Maciej Jórdeczka, Michał Kobusiewicz, Marek Chłodnicki, and Jarosław Kusiak (2013). What forced the prehistoric cattle-keepers to emigrate from the Red Sea mountains?. In: Studia Quaternaria 30 (2), pp. 135-142.

Bryan, Betsy (1991). The reign of Thutmose IV. Baltimore: John Hopkins University Press. Burckhardt, John Lewis (1819). Travels in Nubia. London: Murray.

Burstein, Stanley (1989). Agatharchides of Cnidus: On the Erythraean Sea. London: The Hakluyt Society.

Caminos, Ricardo (1998). Semna-Kumma II: The Temple of Kumma. London: Egypt Exploration Society.

Castiglioni, Alfredo, Castiglioni, Angelo and Vercoutter, Jean (1995). Das Goldland der Pharaonen. Mainz: Philipp von Zabern.

Cooper, Julien (2018). Kushites expressing "Egyptian” kingship: Nubian dynasties in hieroglyphic texts and a phantom Kushite king. Ägypten und Levante 28, pp. 143-167.

Cooper, Julien (2020). Toponymy on the Periphery: Placenames of the Eastern Desert, Red Sea, and south Sinai in Egyptian documents from the Early Dynastic until the end of the New Kingdom. Leiden: Brill.

Cooper, Julien (2020). A Nomadic State? The 'Blemmyean-Beja' Polity of the Ancient Eastern Desert. Journal of African History 61 (3), pp. 383-407.

Cooper, Julien (in press). Children of the Desert: The indigenous peoples of the Eastern Desert in the Pharaonic Period. In: H. Cuvigny, ed, Blemmyes: New Documents and New Perspectives. Institut français d'archéologie orientale.

Cooper, Julien and Barnard, Hans (2017). New insights on the inscription on a painted Pan-grave bucranium, Grave 3252 at Cemetery 3100/320o, Mostagedda (Middle Egypt). African Archaeological Review 34 (3), pp. 363-376.

Couyat, Jules and Montet, Pierre (1912). Les inscriptions hiéroglyphiques et hiératiques du Ouadi Hammamat. Le Caire: Institut français d'archéologie orientale.

Damiano-Appia, Maurizio (1999). Inscriptions along the Tracks from Kubban, Buhen and Kumma to "Berenice Panchrysos" and to the South. In: S. Wenig, ed., Studien zum Antiken Sudan: Akten der 7. Internationalen Tagung für meroitische Forschungen vom 14. bis 19. September 1992 in Gosen/bei Berlin. Wiesbaden: Harrassowitz, pp. 511-542.

Davies, Vivian (2003). Kush in Egypt: a new historical inscription. Sudan \& Nubia 7 , pp. $5^{2-4}$.

Davies, Vivian (2008). Tombos and the Viceroy Inebny/Amenemnekhu. British Museum Studies in Ancient Egypt and Sudan 10, pp. 39-63.

Davies, Vivian (2014). The Korosko Road Project: recording Egyptian inscriptions in the Eastern Desert and elsewhere. Sudan \& Nubia 18, pp. 30-44.

de Souza, Aaron (2019). New horizons: the Pan-Grave ceramic tradition in context. London: Golden House. 
Diego Espinel, Andres (2006). Etnicidad y territorio en el Egipto del Reino Antiguo. Barcelona: Universitat Autònoma de Barcelona.

Dore, Gianni (2007). Kunama. In: S. Uhlig, ed, Encyclopaedia Aethiopica: Volume III. Wiesbaden: Harrassowitz, pp. 453-455.

El-Sayed, Rafed (2011). Afrikanischstämmiger Lehnwortschatz im älteren Ägyptisch. Leuven: Peeters.

FHN (1994-1998) = Eide, Tormod, Hägg, Tomas, Pierce, Richard and Török, László (1994-1998). Fontes Historiae Nubiorum: textual sources for the history of the Middle Nile Region between the eighth century $B C$ and the sixth century $A D$ 3. Bergen. Department of Greek, Latin and Egyptology.

Gardiner, Alan (1947). Ancient Egyptian Onomastica. Oxford: Oxford University Press. Habachi, Labib (1959). The First Two Viceroys of Kush and their Family. Kush 7 , pp. 45-62.

Habachi, Labib (1972). The second Stela of Kamose and his struggle against the Hyksos ruler and his capital. Glückstadt: Augustin.

Harir, Sharif (1996). Adaptive forms and processes among the Hadendowa: coping with unpredictability. In: L. Manger, ed., Survival on meagre resources: Hadendowa pastoralism in the Red Sea Hills. Uppsala: Nordiska Afrikainstitutet, pp. 81-102.

Hatke, George (2013). Aksum and Nubia: Warfare, Commerce, and Political Fictions in Ancient Northeast Africa. New York: New York University Press.

Helck, Wolfgang (1955). Urkunden der 18. Dynastie: historische Inschriften Thutmosis' III. und Amenophis' II. Berlin: Akademie-Verlag.

Helck, Wolfgang (1975). Die große Stele des Vizekönigs St3w aus Wadi es-Sabua. Studien zur Altägyptischen Kultur 3, pp. 85-112.

Helck, Wolfgang (1995). Historisch-biographische Texte der 2. Zwischenzeit und neue Texte der 18. Dynastie: Nachträge. Wiesbaden: Harrassowitz.

Hjort af Ornäs, Anders and Dahl, Gudrun (1991). Responsible Man: The Atmaan Beja of North-eastern Sudan. Uppsala: Nordiska Afrikainstitutet.

Hobbs, Joseph (1989). Bedouin Life in the Egyptian Wilderness. Cairo: American University in Cairo Press.

Kemp, Barry (2006). Ancient Egypt: Anatomy of a Civilisation. London: Routledge.

Kheir, El-Hag M. (1989). A Contribution to a Textual Problem: Ibn Sulaym al-Aswāni's Kitāb Akhbār al-Nūba wa-l-Maqurra wa-l-Beja wa-l-Nīl, Arabica 36:1, pp. 36-8o.

Klemm, Rosemarie and Klemm, Dietrich (2013). Gold and Gold Mining in Ancient Egypt and Nubia. New York: Springer.

Koenig, Yvan (1990). Les textes d'envoûtement de Mirgissa. Revue d'égyptologie 41, pp. 101-125.

Layton, Robert (1986). Political and Territorial Structures Among Hunter-Gatherers. In: Man 21:1, pp. 18-33. 
Liszka, Kate (2010). Medjay (no. 188) in the Onomasticon of Amenemope. In: Z. Hawass and J. Wegner, eds, Millions of Jubilees: Studies in honor of David P. Silverman. Cairo: Conseil Suprême des Antiquités, pp. 315-331.

Manassa, Colleen (2016). The crimes of Count Sabni reconsidered. Zeitschrift für Ägyptische Sprache und Altertumskunde 133, pp. 151-163.

Manzo, Andrea (2017a). Eastern Sudan in its setting: the archaeology of a region far from the Nile Valley. Oxford: Archaeopress.

Manzo, Andrea (2017b). The territorial expanse of the Pan-Grave culture thirty years later. Sudan \& Nubia 21, pp. 98-112.

Marochetti, Fiore (2010). The reliefs of the chapel of Nebhepetra Mentuhotep at Gebelein. Leiden: Brill.

McCabe, J. Terrence (2010). Cattle Bring us to our enemies: Turkana ecology, politics, and raiding in a disequlibrium system. Ann Arbor: University of Michigan Press.

McIntosh, Susan (1995). Pathways to complexity: an African perspective. In: S. McIntosh, ed., Beyond Chiefdoms: Pathways to Complexity in Africa. Cambridge: Cambridge University Press, pp. 1-30.

Morton, John (1989). Descent, Reciprocity and Inequality among the Northern Beja. Dissertation, Department of Sociology and Social Anthropology, University of Hull.

Piotrovsky, Boris (1983). Vadi Allaki, put' k zolotym rudnikam Nubii: drevneegipetskie naskal'nye nadpisi [ВАДИ АЛЛАКИ-путь к золотым рудникам Нубии]. Moskva.

Posener, Georges (1940). Princes et pays d'Asie et de Nubie: textes hiératiques sur des figurines d'envoûtement du Moyen Empire. Bruxelles: Fondation Égyptologique Reine Élisabeth.

Posener, Georges (1987). Cinque figurines d'envoûtment. Le Caire: Institut français d'archéologie orientale.

Redford, Donald (2004). From Slave to Pharaoh: The Black Experience of Ancient Egypt. London: Johns Hopkins University Press.

Ryholt, Kim (1997). The political situation in Egypt during the Second Intermediate Period c. 1800-1550 BC. Copenhagen: Museum Tusculanum Press.

Sadr, Karim, Alfredo Castiglioni and Angelo Castiglioni (2004). The Archaeological Sequence in the Nubian Eastern Desert: CeRDO's Explorations 1989-1994. In: S. Wenig, ed, Neueste Feldforschungen im Sudan und in Eritrea. Wiesbaden: Harrassowitz, pp. 191-204.

Scharff, Alexander (1922). Ein Rechnungsbuch des königlichen Hofes aus der 13. Dynastie (Pap. Boulaq Nr. 18). Zeitschrift für Ägyptische Sprache 57, pp. 51-68.

Schulman, Alan (1982). The Nubian war of Akhenaton. In: Anonymous, ed, L'Égyptologie en 1979: axes prioritaires de recherches. Paris: Éditions du Centre national de la Recherche scientifique, pp. 299-306. 
Sethe, Kurt (1926). Die Ächtung feindlicher Fürsten, Völker und Dinge auf altägyptischen Tongefäßscherben des Mittleren Reiches: nach den Originalen im Berliner Museum. Berlin: de Gruyter.

Sethe, Kurt (1933). Urkunden des Alten Reichs I. Leipzig: Hinrichs.

Smither, Paul (1945). The Semnah despatches. Journal of Egyptian Archaeology 31, pp. $3^{-10 .}$

Sneath, David (2007). The Headless State: Aristocratic Orders, Kinship Society, \& Misrepresentations of Nomadic Inner Asia. New York: Columbia University Press.

Török, László (1997). The kingdom of Kush: handbook of the Napatan-Meroitic civilization. Leiden. Brill.

Török, Laszlo (2009). Between two Worlds: The Frontier Region between Ancient Nubia and Egypt $3700 \mathrm{BCE}-500 \mathrm{AD}$. Leiden: Brill.

Vercoutter, J. (1959). The Gold of Kush. Kush 7, pp. 120-153.

Vernus, P. (1986). Études de philologie et de linguistique (V), Revue d'égyptologie 37, pp. 141-143.

Wedekind, Klaus (2010). More on the Ostracon of Browne's Textus Blemmyicus. Annali 70 (2010), pp. 73-81.

Wente, Edward (1990). Letters from Ancient Egypt. Atlanta: Scholars Press.

Williams, Martin (2019). The Nile Basin: Quaternary Geology, Geomorphology and Prehistoric Environments. Cambridge: Cambridge University Press.

Zibelius, Karola (1972). Afrikanische Orts- und Völkernamen in hieroglyphischen und hieratischen Texten. Wiesbaden: Reichert.

Zibelius-Chen, Karola (1994). Die Kubanstele Ramses' II.: und die nubischen goldregionen. In: C. Berger, G. Clerc, and N. Grimal, eds, Hommages à Jean Leclant. Le Caire: Institut français d'archéologie orientale, II, pp. 411-417.

Zibelius-Chen, Karola (2006). Ein weiterer Beleg zum sprachlichen Kontinuum des Medja-Bedja (Tu-bedauye). In: G. Moers, H. Behlmer, and K. Demuß,. Widmaier, eds, Jn.t dr.w Festschrift für Friedrich Junge. Göttingen: Lingua Aegyptia, pp. 729-735. 